\title{
A FILOSOFIA EM PROL DA RELIGIÃO: O MOVIMENTO ESCOLÁSTICO NA IDADE MÉDIA CENTRAL (XI-XIII)
}

PHILOSOPHY FOR RELIGION: THE SCHOLASTIC MOVEMENT IN THE CENTRAL MIDDLE AGE (XIXIII)

\section{RESUMO}

O presente artigo tem como objetivo investigar o surgimento do movimento filosófico denominado de Escolástica no contexto cultural e educacional da Idade Média Central, entre os séculos XI e XIII. Nesse sentido, discutiremos como o advento das universidades medievais esteve atrelado ao desenvolvimento do método escolástico como pensamento filosófico. Em seguida debateremos como esse modo de pensar e modelo de estudo foram legitimados pelas universidades religiosas para o estudo dos livros dos Pais Latinos, os textos canônicos, das Sagradas Escrituras e das Sentenças de Pedro Lombardo, sendo essas obras verdadeiros instrumentos de trabalho, partir dos quais obras teológicas e filosóficas foram escritas, como a Summa Theologiae (1273), de Tomás de Aquino. Por fim, analisaremos como esse movimento foi contestado e contrariado internamente, visto que dentro das universidades os representantes das ordens religiosas dos Franciscanos e dos Dominicanos, os mestres eclesiásticos, realizavam refutações aos métodos adotados pela prática filosófica de pensamento escolástica.

PALAVRAS-CHAVE: Escolástica. Método. Tomás de Aquino. Universidades. Filosofia.

\section{ABSTRACT}

This article aims to investigate the emergence of the philosophical movement called Scholastics in the cultural and educational context of the Central Middle Ages, between the 11th and 13th centuries. In this sense, we will discuss how the advent of medieval universities was linked to the development of the Scholastic method as philosophical thinking. Then we will discuss how this way of thinking and model of study was legitimized by religious universities for the study of the books of the Latin Fathers, the canonical texts, the Sacred Scriptures and the Sentences of Peter Lombardo, these works being true instruments of work, to the extent that from this method theological and philosophical works were written, such as Thomas Aquinas' Summa Theologiae (1273). Finally, we will analyse how this movement was challenged and opposed internally, since within the universities the representatives of the Franciscan and Dominican religious orders, the ecclesiastical masters, made refutations to the methods adopted by the philosophical practice of scholastic thought.

KEYWORDS: Scholastics. Method. Thomas Aquinas. Universities. Philosophy.

\footnotetext{
* Doutorando em História Medieval pelo Programa de Pós-Graduação em História da Universidade Federal do Espírito Santo, sob orientação do Prof. Dr. Sérgio Alberto Feldman. Membro do Laboratório de Estudos Tardo Antigos e Medievais Ibéricos Sefaradis (Letamis). E-mail: gattpablo@gmail.com.
} 


\section{INTRODUÇÃO}

Estudar a filosofia da Escolástica como um movimento autônomo, fora do contexto econômico e social do Medievo, implicaria um estudo simplório, pois uma série de elementos foi-se desenvolvendo juntamente a essa filosofia ao longo da Idade Média Central (XI-XIII). Estamos falando aqui do renascimento do comércio e das cidades, do surgimento das Universidades e a nova organização das profissões em corporações de ofício, mecanismos que acompanharam o caminhar e foram objeto de estudos da filosofia da Escolástica.

No final do século XI e início do século XII encontramos uma mudança no interior das instituições da sociedade feudal. Mudanças essas que permearam as relações e os modos de trabalho, na passagem de um mundo rural para um mundo citadino. Podemos elencar três fatores que propiciaram essas mudanças e, consequentemente, fortificaram novos hábitos. $\mathrm{O}$ primeiro fator foi o movimento das Cruzadas, que promoveu o contato com o Oriente e trouxe uma reinterpretação das coisas da natureza aob a influência dos escritos de Aristóteles, antes explicadas pela revelação contida nas Sagradas Escrituras.

Temos também o movimento reformador que ocorreu no interior Igreja no século XI, que buscará se sobrepor aos demais estamentos da sociedade. Com o Dictatus Papal, de Gregório VII, não houve apenas uma reforma na Igreja, mas do mesmo modo uma tentativa de colocar sua autoridade soberana sobre toda a sociedade, controlando a nomeação de bispos do clero. A Instituição religiosa estava interessada em conduzir o governo da cristandade latina, ao alegar ser a detentora da verdade porque era perfeita. Nesse sentido, vemos uma luta entre os dilemas das coisas terrenas e espirituais, uma vez que a própria Igreja reconheceu o poder que dispunham os príncipes. Esse poder, inflamado posteriormente com a Batalha de Bouvines de 1214, está representado por Felipe Augusto que sai dessa guerra como um rei com características nacionais, como se o reino tivesse ganhado a batalha, ameaçando a fragmentação do Estado teocrático criado pela Igreja cristã (OLIVEIRA, 2006, p. 27). Boa parte do clero também fora contra o Dictatus Papal, alegando um princípio de autoritarismo por parte do papa. Esse debate entre as coisas terrenas e espirituais implicará o surgimento das Universidades, pois príncipes e papas criaram tais instituições de ensino como forma de defesa de seus poderes.

Outro evento que provocará uma mudança efetiva no século XIII está ligado ao renascimento do comércio e das cidades, sendo que esse comércio só terá vivência no espaço da urbis. Cidade e comércio surgem concomitantemente no interior do mundo feudal e 
contribuem para o nascimento da burguesia. Foram essas novas três condições e elementos que influenciaram na construção da nova sociedade nascente na Idade Média Central.

Nesse novo espaço citadino as relações sociais acontecem entre os mais diversos segmentos, provocando uma profunda mudança no conceito de temporalidade, que antes era propriedade da Igreja, pois "a vida das pessoas passa a ser regida pelo relógio e não mais pela natureza" (OLIVEIRA, 2006, p. 29). Antes tínhamos um mundo marcado pelo badalar dos sinos, agora, no contexto da Idade Média Central, vemos um novo mundo regido pelo tempo das feiras e pelo trabalho dos artesões. O trabalho intelectual, do mesmo modo, deixa de ser entendido pela graça divina e passa a ser compreendido por seu valor profissional. Esses intelectuais eram o prolongamento das cidades, pois mediante essa nova realidade novas disciplinas, técnicas cientificas e artesanais precisavam ser desenvolvidas. O ensino passa a ter um papel a ser cumprido em sociedade, em que o estudo perpassa pelo viés do trabalho e precisa ser divulgado para todos.

Com as mudanças ocorridas no interior do Medievo Central, a velha forma de explicação do mundo já não oferecia mais uma resposta favorável aos demais estamentos, visto que agora existem divisões exigidas pelos efeitos do trabalho. A divisão antiga, pautada entre sagrado e profano, concede lugar à nova concepção das relações sociais, em que nos deparamos com as corporações de ofícios, que não encontravam um lugar na explicação do mundo pelo viés teológico. Era necessário uma nova explicação e renovação das formas de descrição do homem, da sociedade, da natureza e de Deus. Nesse contexto podemos entender o surgimento da Universidade em conjunto com a Escolástica, dado que essa filosofia implicava a busca de uma nova e diferente teoria para explicar e legitimar as coisas humanas e terrenas (OLIVEIRA, 2010, p. 272). Essas mudanças que ocorreram no interior da sociedade colocaram em contestação o antigo modo de explicação do mundo pela fé, sendo que o viés teológico negava um novo homem prestes a nascer e que seria capaz de mudar sua realidade independentemente da razão divina.

Mesmo com a justificação da sociedade em três ordens, laboratores, belatores e oratores, (os que trabalham, os que defendem e os que oram), no formato de uma sociedade tripartite, a Igreja não era mais vista como uma força histórica e natural, pois as corporações de ofício não se encaixavam em nenhuma das ordens citadas. Diante dessas transformações a Instituição religiosa passa de base fiadora da sociedade para lutar com seus instrumentos na conservação do seu poder. Foi uma luta que se iniciou no século XI, entre os dois poderes, e 
que terá no século XIII o fortalecimento da realeza como forma e força expressiva no cuidado do bem público.

Os questionamentos dos homens do Medievo Central estão ligados ao fato de que a Igreja deixa de corresponder aos anseios da sociedade, sua divisão de mundo, pautada nas três ordens, já não contemplava mais a realidade do período em questão. A nova realidade exigiu uma nova explicação das coisas da natureza, dado que o poder que a Igreja havia cristalizado será colocado em debate. A Igreja correspondia ao que os homens esperavam do que conhecemos hoje como Estado, porque durante os séculos VI até o XI aquela foi a única Instituição capaz de estabelecer os princípios de governo. Quando a Igreja passou a não responder as querelas ligadas às novas forças sociais, provenientes das cidades, do comércio, da fé e da razão, o poder da Instituição religiosa foi questionado em seus fundamentos. Discussão que se estendeu até o século XIV.

Como que a Escolástica se insere nesse contexto? Ao mesmo tempo em que os representantes da Igreja deixaram de se aproximar dos problemas sociais e passaram a se interessar pelos próprios problemas, as novas forças sociais emergiram com a possibilidade de assumir o governo da sociedade. A crise interna da Igreja, que começou no século XI, gerou críticas ao poder e posição da mesma frente às mudanças no interior da comunidade medieval. Nesse sentido, o poder real foi sendo fortalecido e ganhou forças fora do domínio da Igreja. Era preciso, agora, definir qual era o papel de cada ordem na sociedade.

No século XIII verificamos a cisão entre o poder da Igreja e o poder da realeza, sendo que o poder do príncipe laico se tornou preponderante na sociedade. A partir de então esses dois poderes lutaram pelo governo do social e buscaram novas formas de descrição das coisas do mundo, encontrando nas Universidades a base para a sustentação de suas respectivas explicações acerca dos elementos divinos e terrestes. Os mestres escolásticos se dividiram entre o apoio dos dois poderes, pois as Universidade desempenharam um papel crucial no desenvolvimento da sociedade do século XIII, tornando-se o centro das atenções de autoridades laicas ou clericais. Nesse sentido, a consolidação da vida urbana e o renascimento do comércio, juntamente com as corporações de ofício, trouxeram uma efervescência de discussões, já que a fé não podia explicar tudo.

Do mesmo modo que o século XIII marca o período de maior brilho do Medievo, com o movimento filosófico da Escolástica e o uso da razão (OLIVEIRA, 2006, p. 25), marca-se também o início do declínio do período em questão. As novas Instituições e as novas relações humanas propiciaram mecanismos para a contestação dos princípios religiosos e laicos. Uma 
nova realidade e nova forma de pensamento surgem com a separação da filosofia da teologia, em que Duns Escoto, já no século XIV, e Guilherme de Ockham defendem a não submissão da essência divina às análises da razão natural. Pós-ascensão das Universidades, as quais já não correspondiam mais aos anseios dos homens da época, pois no século XV os renascentistas e humanistas negavam a cultura do Medievo, na defesa de uma cultura livre e na proposta de libertação da razão teológica. São novas formas de pensar em uma nova época, em que se promove um pensamento antirracionalista, na tentativa de criação de novas estruturas para se explicar o novo mundo.

\section{O SURGIMENTO DAS UNIVERSIDADES MEDIEVAIS}

As Universidade medievais foram promotoras de um novo processo educativo que, diferentemente das escolas ${ }^{1}$ do período em questão, estimulavam seus alunos a pensarem e contestarem o objeto de estudo. Tais Universidades caracterizaram-se como agentes de uma nova relação social, pois, além de formarem um novo espaço do saber, funcionaram como respostas às necessidades e demandas geradas pelo desenvolvimento da urbanidade e das formas de produção mercantil e de comércio surgidas no início da Idade Média Central.

Por Universidade entendemos, do latim clássico, o termo universitas, que significa totalidade ou todo; um local em caráter comunitário ou grupal e por isso não pode ser estudado em seu contexto particular e individual. As Universidades nasceram conjuntamente com o método e a filosofia da Escolástica. Esse método nada mais foi que a forma magistral de ensino em que as Universidades estavam alicerçadas, sendo essas instituições de ensino o desdobramento de todas essas mudanças ocorridas no interior da sociedade Centro-Medieval (XI-XIII). O profissional intelectual passou a ser visto como um profissional do ofício, pois os professores se organizaram em corporações de ofício, cujo nome é Universidade.

Encontramos a base para esse modelo de pensamento nas fundamentações teóricas propostas pelas escolas medievais dos séculos XI e XII, visto que as Universidades surgiram apenas no século XIII, reelaborando o método de ensino presente nessas escolas com

\footnotetext{
${ }^{1}$ As escolas medievais são fruto do Renascimento Carolíngio no século VIII, promovido por Carlos Magno. O processo de educação era responsabilidade da Igreja, pois essas escolas estavam localizadas em anexos às catedrais ou em mosteiros. Essas escolas foram importantes veículos para a formação da filosofia medieval, sendo que nessas instituições foram criados métodos de pensamento e ensino, em que encontramos a base da Escolástica, a lectio. Elas deram alicerce para a criação das Universidades, entretanto não são uma extensão destas, visto que nelas estimulava-se apenas a reprodução do conteúdo. O papel das Universidades foi o de criar um novo espaço de saber, sendo sua essência a produção teórica e o conhecimento científico.
} 
características próprias ao modelo universitário. Tanto a Escolástica como a Universidade estiveram vinculadas à vida e às ações dos homens medievais, refletindo a forma como esses homens se expressavam e explicavam as coisas do mundo. Podemos afirmar que esse conhecimento é próprio do período em questão, pois a filosofia cristã, de caráter original, tem sua base teórica fundamentada nas escolas medievais. Posteriormente ao Renascimento Carolíngio, promovido por Carlos Magno no século VIII, encontramos as escolas monásticas, depois as palacianas e por fim as Universidades, em que todas essas instituições adotaram o método da lectio, que é a repetição constante da leitura do objeto a ser estudado. Foram as escolas, ao longo da medievalidade, as responsáveis por elaborarem a filosofia cristã pautada no método da lectio. Foi uma tradição de caráter oral que mais tarde se transformaria nas famosas Summas de Teologia.

As primeiras Universidades foram criadas entre os anos de 1215 e 1225 . São elas as Universidades de Bolonha, Paris e Oxford. É por esse novo contexto, resultante das modificações realizadas nas relações sociais do início do século XI, que podemos entender o surgimento das Universidades, visto que estas não são uma extensão das escolas medievais. Cada uma dessas Universidades estava engajada com um ensino específico, quando temos em Bolonha o ensino da medicina, Paris com o ensino da Teologia e Filosofia e Oxford em seu caráter empírico e da investigação matemática. É um novo locus do saber que não pode ser explicado separadamente dos eventos citados no tópico acima.

Em um primeiro momento temos uma Universidade fechada em si. Essa cultura autônoma se explica pela não aceitação dos saberes provindos de outras fontes a não ser das Sagradas Escrituras. É uma cultura fechada no que tange ao corpo universitário, detentor dos verdadeiros saberes e que desprezam qualquer conhecimento exterior, como as obras de cunho aristotélico sob pena de excomunhão. Os mestres escolásticos alegavam que o saber autêntico estava nas salas de aulas, no corpo de clérigos que falam do alto e nos textos canônicos, como instrumento de ensino, escritos em latim.

Os instrumentos utilizados pelos mestres eclesiásticos são os livros dos Pais Latinos ${ }^{2}$. Eram textos canônicos de teor primordial. Posteriormente ao século XII, temos com Pedro

\footnotetext{
${ }^{2}$ Do latim pater, os Pais ou Padres da Igreja foram importantes teólogos da Igreja dos primeiros séculos que, a partir da segunda metade do século IV, exerceram enorme influência na formulação da doutrina cristã. São os homens que "cunharam a vida da comunidade católica." (PADOVESE, 1999, p. 19), que ensinaram e permaneceram na fé. A partir do século IV, pelo decreto De libris recipiendis et non recipiendis, o termo se concentra em todos os representantes da tradição eclesiástica, logo em seguida aplicado aos que levaram uma vida monástica ou ascética. Por fim, a ortodoxia ou heresia de uma doutrina será avaliada por meio dos ensinamentos
} 
Lombardo, Graciano e Abelardo sínteses dos escritos desses autores antigos, os Padres ou Pais da Igreja, em seu conteúdo essencial (ALESSIO, 2006, p. 369). Em um segundo momento, já no final do século XII e no início do XIII, esses mestres do saber recebem textos mulçumanos e do saber grego traduzidos para o latim. Sem essas traduções a Escolástica não existiria, pois são por essas traduções que Tomás de Aquino elabora os seus escritos juntamente às Sagradas Escrituras.

A filosofia da Escolástica, dentro das Universidades medievais, tem como sua tarefa principal o comentário, em que o corpo de mestres permanecerá como um corpo de comentadores. Como cultura fechada a Universidade esteve fragmentada em saberes, no formato de Universidades independentes (Artes, Direito, Medicina e Teologia), mas foi a sua base de ensino que garantiu o caráter de unidade da Escolástica. É a Faculdade de Artes que detém a base para o ensino das demais disciplinas, pois para se tornar um mestre do saber se faz necessário adquirir o saber filosófico que somente a Faculdade de Artes promove. A filosofia é o tronco comum da Universidade e do método Escolástico. É por esse saber que podemos falar de uma Escolástica no singular, pautada e principiada pelo saber filosófico. Nesse sentido, entendemos a Universidade como plural e quádrupla, porém unitária em seu método escolástico de ensino, propiciado unicamente pela Faculdade de Artes.

Esse método Escolástico também recebe a denominação de Organon. É uma técnicalinguística que permite o comentário, sendo uma "técnica que permanece a mesma em teologia, em direito e em medicina, que é aprendida na faculdade de artes, mas impõe-se em todas as outras faculdades. Portanto, é a maneira de proceder que fornece a unidade ideal da Escolástica" (ALESSIO, 2006, p. 371). É um método pautado no princípio diretor da autoridade dos textos portadores da verdade, os textos presentes nas Sagradas Escrituras. Esses textos refletiam uma visão tipicamente cristã e neles os mestres universitários acreditavam estar a chave para a salvação da alma.

Como lição oral, a lectio se tornou o pilar magistral da Escolástica. Por esse método se desenha o comentário organizado de maneira metódica. É uma leitura comentada dos textos aprovados pelo corpo de mestres, leitura principalmente fundamentada nas Sagradas Escrituras e nas Sentenças de Pedro Lombardo.

O século XIII marcou o amadurecimento da sociedade medieval juntamente com o apogeu da Escolástica, em que as Universidades eram uma “corporação cuja preocupação era a

deixados por eles, pois inauguraram a "ciência" da teologia e forjaram a centralidade da palavra de Deus como essência da Sacra Pagina.

Sapere aude - Belo Horizonte, v. 11 - n. 22, p. 417-433, Jul./Dez. 2020 - ISSN: 2177-6342 
difusão e elaboração do conhecimento do qual Tomás de Aquino foi um importante mestre universitário" (SANTIN; OLIVEIRA, 2009, p. 3). Esse conhecimento profundo da natureza humana e o compromisso com a civilização cristã ocidental e medieval foram as bases para a formação do mestre religioso do século XIII. É esse projeto de civilização, que tem o fim último da salvação, que dá sentido à ação do mestre. É uma relação entre formação docente com o campo da ética, em que existe uma série de princípios e valores na formação pedagógica e de pressupostos teórico-práticos. Somente seguindo esse esquema didático é que o mestre estaria apto em sua formação educativa.

Ademais, a educação e a religião foram parte do mesmo processo educativo do indivíduo do século XIII (OLIVEIRA, 2011, p. 1). A formação dos mestres acompanhou o universo e mundo dos livros, sendo esses os profissionais encarregados de comentarem os textos sagrados que têm autoridade. Agora sim podemos falar de uma Universidade em seu funcionamento como um corpo fechado constituído por mestres.

Por Escolástica entendemos o conjunto de doutrinas, opiniões e métodos que se desenvolveram nas universidades medievais; de certo modo o método escolástico começou quando começaram as universidades, em parte deriva daí, ou se justifica, o seu nome de escolástico, próprio da escola. (LUPI, 2013, p. 171).

É nesse âmbito que o método da Escolástica se consolidou, pois trouxe novas formas e explicações acerca das coisas do mundo. Ademais, essa "filosofia que se desenvolveu nas universidades medievais estava metodologicamente estruturada de um modo didático que lhe valeu o apelido de 'Escolástica"” (LUPI, 2013, p. 170), incorporando os modos de argumentação já desenvolvidos nas escolas, porém lhes dando uma formatação própria. Com isso a Escolástica constituiu a Teologia e a Filosofia como ciências próprias de seu tempo.

\section{A FILOSOFIA DA ESCOLÁSTICA: O MÉTODO ESCOLÁSTICO DE ENSINO}

O período que compreende a Idade Média Central (sécs. XI-XIII) foi marcado por profundas mudanças no interior do pensamento filosófico. A filosofia abarcou vários métodos ao longo dos séculos, métodos expositivos ou argumentativos, em que cada um em seu modo contribuiu para a formação do método filosófico medieval. Com os pré-socráticos temos a defesa e busca pela razão das coisas. Na Atenas do século V a.C., encontramos a maiêutica, método que influenciará e propiciará o diálogo nas formas de governo e no meio social. Nesse contexto democrático, do período ateniense, a verdade não se fecha em si, pelo contrário, está 
sempre aberta aos diálogos que possam surgir das demais opiniões. Em Aristóteles, do mesmo modo, percebemos em seus diálogos que as opiniões são comparadas e discutidas, assim como na Roma antiga, em que a filosofia tem sua linguagem mais acessível ao dividir os saberes no número (Quadrivium) e na palavra (Trivium). Com o advento da religião cristã a filosofia incorporou os modelos antigos já existentes, porém permeada pela prática da exegese dos textos bíblicos (LUPI, 2013, p. 173-174). No Cristianismo a filosofia aderiu ao caráter do religioso, sendo as coisas do mundo explicadas agora pela revelação contida nas Sagradas Escrituras, em que essa revelação paulatinamente adere à meditação filosófica.

A religião cristã mantém o método do diálogo no campo da filosofia, mesmo que legitimada por um teor religioso, pois o modelo clássico foi sendo substituído por intenções morais e religiosas. Com Agostinho de Hipona vemos uma perda da racionalização no campo filosófico, em que a pedagogia da alma ascende ao campo do questionamento. A temática discutida, nesse momento, será a do aperfeiçoamento das virtudes para o engrandecimento da alma, na correção dos erros carnais. O Bispo de Hipona sai em defesa de que o corpo está fortemente inclinado às coisas da carne, que são opostas ao espírito. Em sua filosofia, conhecer as particularidades da alma passou a ser o conhecimento de si mesmo, sendo o homem o objeto central. Esse método filosófico cristão estará pautado na catena, cadeia de citações de autoridades cristãs.

No contexto dos séculos do Medievo Central, o método de filosofar cristão já não mais atendia às necessidades dos homens do período. Novas questões surgem e são usadas no combate à filosofia cristã tradicional, ocorrendo uma revisão de toda metodologia anterior, que assume seu máximo aperfeiçoamento com a Escolástica. Nesse sentido, o pensamento do período esteve repleto por uma intensa designação simbólica ${ }^{3}$, seja no panorama imagético, em como os homens desse tempo concebiam o universo, ou no próprio campo da filosofia.

Em muito a filosofia da Escolástica contribuiu à Idade Média Central. Por esse método de ensino surgiram novas compreensões das relações sociais, da economia, da política e da cultura material (BARROS 2012, p. 231). Esse movimento sinalizou as transformações

\footnotetext{
${ }^{3}$ Os símbolos são acontecimentos, gestos ou atos que transmitem um significado. Influenciam no comportamento dos homens ao classificarem o mundo e introduzirem valores. Quando disputados, os símbolos são objetos que detêm o monopólio sobre algo, uma vez que justificam uma ordem social (GEERTZ, 2008, p. 179). Interessante notar que para Michel Pastoureau (2004, p. 12), os símbolos, ou melhor, o Symbolon, na cultura grega é "sempre ambíguo, polivalente, proteiforme (que muda frequentemente de forma); ele não pode ser resumido em qualquer fórmula."
} 
histórico-sociais que atravessam várias fases da Idade Média, com Anselmo da Cantuária, Abelardo, Francisco de Assis, Tomás de Aquino e Guilherme de Ochkam.

Guardando íntimas relações com as Universidades medievais, a Escolástica esteve pautada no princípio de autoridade dos textos canônicos, dos quais os mestres deveriam extrair todo o conhecimento. De início fomentou um padrão autossuficiente e fechado em si, sendo os atores sociais desse universo intelectual os membros das Ordens Mendicantes. A missão desses agentes do saber era a de convencer por meio da pregação, em um formato especial de pensar e de falar, os hereges ou estamentos mais baixos. A Ordem dos Dominicanos utilizou o método Escolástico como base essencial para a formação de seus mestres. Esses mestres eram encarregados do combate às heresias, pois quem fugia dessa universalidade cristã era um transgressor. A pregação deveria "recompor um quadro de fiéis que se vê abalado desde o século XII por novas e por vezes ameaçadoras formas de religiosidade. Logo adiante, tornarse-ão também os inquisidores oficializados pelo Papado" (BARROS, 2012, p. 233).

Escolástica pode ser entendida, então, como "conjunto das doutrinas literárias, filosóficas, jurídicas, médicas e teológicas, e mais outras científicas, que se elaboraram e corporificaram no ensino das escolas universitárias do século XII ao XV” (NUNES, 1979, p. 244). O método em questão esteve pautado, majoritariamente, nos textos canônicos, em que deles eram retirados os problemas a serem discutidos pelo mestre e alunos, sendo sua base o desejo de explicar tudo. Podemos dizer que esse método de ensino privilegiava três passos, partindo da leitura do texto canônico, posteriormente com o comentário literal da palavra e da gramática e findando em uma explicação lógica acerca do assunto. Esse modelo foi constituído por três práticas essenciais, pela Lectio, já praticada nas escolas medievais, pela Quaestio e pela Disputatio, respectivamente a leitura dos textos pelo mestre aos alunos, a análise das questões e problemas contidos no texto e o debate e a reflexão entre os mestres e alunos. Podemos ainda inserir um quarto método, posterior à leitura, que é a Expositio, na explicação dos possíveis fatos. Esses elementos funcionaram como norteadores do saber produzido nas Universidades, visto que se iniciava com a leitura pelo mestre dos textos canônicos e findava no levantamento de resoluções importantes para o convívio social e discutidos no modelo da dialética. Pela necessidade do diálogo se fazia necessário deter a precisão do vocabulário.

A disputatio foi a essência e novidade promovida pelas Universidades medievais. Por esse método gerava-se uma cadeia de discussão, iniciando-se pelo levantamento de um problema pelo mestre, logo depois levantava-se uma hipótese, seguida por objeções a essa hipótese, e contraobjeções também eram colocadas em práticas. No final da discussão o mestre 
explanava suas conclusões ao tema iniciado. O mestre, em sua característica de sábio, era um orientador ético para o bom uso da sabedoria. O diálogo, nessa filosofia de interpretação das coisas da natureza, se fez presente em todo o momento, sendo uma discussão entre o mestre e seus alunos, provando ser possível divergir sem que o adversário se torne um inimigo (OLIVEIRA, 2019, p. 6).

Ainda no método escolástico, na segunda metade do século XIV, podemos encontrar as Quaestiones disputatae, em que se levantavam problemas ordinários e que eram discutidos em cada curso. Também podemos encontrar as Quaestiones quodlibet, que versavam problemas extraordinários e gerais e que eram discutidas por todos os cursos da Universidade (Direito, Medicina, Teologia e Artes), em uma data específica, na Páscoa ou no Natal. Esses métodos tinham funções extremamente importantes, pois a partir deles as discussões e o conhecimento eram estimulados. Por esse método os conhecimentos teóricos e a possibilidade da argumentação eram ensinados. As aulas foram os verdadeiros centros vivos de dinâmica do saber, sendo que onde não há discussão, não há disputa. $\mathrm{O}$ método escolástico foi um duelo entre a aparência e a verdade.

Embora somente o mestre detenha o conhecimento necessário para ministrar as aulas, ele não é um auctoristas, "seus juízos não têm o valor de que se revestem os da autoridade, mas sua função consiste em penetrar na palavra autorizada e indicar-lhe o sentido autêntico. A lição do mestre escolástico é, pois, um exercício original que se distingue da antiga lição dos monges" (ALESSIO, 2006, p. 372). O protagonista na filosofia da Escolástica é o intelecto metodicamente organizado, sendo as questões voltadas à natureza do homem o elemento primordial. Por esse viés não podemos atribuir ao método escolástico o caráter de dogmático. A filosofia da Escolástica vale-se da indagação.

Nessas aulas em que as discussões proviam o cerne do aprendizado, inúmeras anotações eram feitas por parte dos alunos. Essas notas, chamadas de relationes, mais tarde viraram fontes sobre a filosofia da Escolástica, sobre o método de ensino escolástico. A obra Collationes in Hexaemeron é uma série de palestras inacabadas, proferidas por Boaventura em Paris do ano de 1723. Essa obra existe mediante transcrições feitas pelos ouvintes do curso.

A preocupação do método residia em proporcionar um ensino reflexivo que possibilitaria diferentes concepções acerca do tema discutido. Seu caráter filosófico estava concentrado justamente nessa questão, pois as discussões versavam os temas que atingiam a sociedade, o homem e a natureza, orientando as pessoas para o enfrentamento dos problemas 
do seu presente. Foi uma filosofia que funcionou como teoria e método, um modo de pensar de duas faces, da ideia e da ação.

No século XIII os protagonistas da Escolástica são os mestres provindos das Ordens Mendicantes, os franciscanos e os dominicanos. Foram essas ordens que edificaram a Escolástica Teológica, em que são ao mesmo tempo sujeitos dessa filosofia. Os mestres dessas ordens trazem em seu seio, respectivamente, a defesa da tradição e a novidade, novas autoridades do saber. Esse mesmo século marca os embates surgidos dentro das Universidades, entre os mestres seculares e os mestres mendicantes, que desejam maior espaço de argumentação. Essas discussões versavam posições acerca do homem e visões fincadas em Aristóteles.

Em Paris encontramos o centro da cristandade latina e a sua Universidade como o centro das luzes. É nesse centro que vemos o grande debate acerca da novidade que é a inserção das obras de Aristóteles, com Tomás de Aquino no século XIII. O Aquinate defende que o mestre, na qualidade de sábio, deverá procurar a verdade aonde quer que ela esteja, por isso Aquino sai em defesa das leituras neoaristotélicas. Essa assimilação modificou o modo de pensar as coisas terrenas e espirituais, pois abrange em seu bojo um modelo de sociedade abarcado pelos mais humildes até o soberano, pensando o indivíduo em sua totalidade.

Essa filosofia teve o seu apogeu com Tomás de Aquino, na junção dos elementos da fé com o princípio da razão, na tentativa de entendimento das coisas do mundo. É por meio dos árabes, com o médico Avicena e o filósofo Averróis, que os conhecimentos mais amplos sobre a ética, física e metafísica, nos escritos de Aristóteles, chegam à Europa. O Doctor Angelicus defende a filosofia de Aristóteles para a compreensão das coisas inferiores, como o homem, a natureza e a matéria corpórea. Entretanto, a filosofia aristotélica não se aplica ao entendimento e ao estudo das Sagradas Escrituras. O monge dominicano é cuidadoso ao ponto de não haver uma usurpação de um conteúdo pelo princípio errado. Tomás de Aquino entende que todo o domínio da filosofia pertence exclusivamente ao campo da razão, em que se deve admitir apenas o que é acessível à luz natural e demonstrável por seus recursos. À teologia cabe o oposto, a revelação divina (SANTIN; OLIVEIRA, 2007, p. 3). São diretrizes vinculadas às diferentes culturas, mas que promovem um Aristóteles ligado ao natural e ao curioso, ao que em latim chamamos de curisitas.

Com Tomás de Aquino as questões humanas passam a não serem tratadas exclusivamente pelo entendimento da fé, pois o advento da razão invade o campo filosófico. A religião, no entendimento de Aquino, não é mais o único vetor explicativo para o emaranhado 
de acontecimentos promovidos pelos novos agentes do século XIII, as cidades, as Universidades, a corte e as corporações de ofício. O dominicano legitima, com o uso da razão, as diferenças sociais trazidas por esse novo contexto do Medievo Central. Para explicar essa nova divisão promovida pelo trabalho, Aquino defende que cada indivíduo nasce com uma função na sociedade.

$\mathrm{Na}$ filosofia de Aquino vemos o alinhamento do racional de Aristóteles com o que é revelado por Deus por meio da fé. O uso da base aristotélica garantiu o teor ético e lógico para o método escolástico, visto que os escritos do filosofo grego, como Ética a Nicômaco (349 a.C), estavam destinados ao Bem Supremo, que é e sempre será a felicidade. Nessa obra Aristóteles sai em defesa de que a prática de ações corretas e justas tornam os homens virtuosos. A fé e a razão convergem para a formulação ideal de uma verdade, sendo Aquino o responsável por sistematizar o equilíbrio entre ambos os princípios de entendimento das coisas do mundo.

A Summa Theologiae (1273), obra mais famosa de Tomás de Aquino, é o reflexo do método escolástico na prática da Disputatio. É o resultado também do equilíbrio entre os princípios da fé com os da razão aristotélica, em um balanço entre os entendimentos filosóficos e teológicos. Suas questões não são resultadas das anotações de sala de aula, foram escritas para auxiliarem o diálogo. Logo em seu prólogo, escrito por Aquino, vemos a defesa de que a obra assume o caráter eminentemente pedagógico. A Summa Theologiae nada mais é que um resumo sistemático da ciência do Aquinate, que desejava que os iniciantes no saber teológico tivessem acesso à doutrina sagrada de forma direta e explicativa (OLIVEIRA, 2013, p. 44).

A Escolástica foi um movimento filosófico em seu saber completo, sendo as Summas sua forma mais perfeita, em que tudo se explicava a partir de princípios firmes. Essas obras foram um tipo de gênero adotado por essa filosofia, em que percebemos que o diálogo não fecha a continuidade do pensamento; pelo contrário, ele inclui outras opiniões e não se contradiz em suas definições. São obras em que os textos foram cuidadosamente subdivididos. Nelas estão presentes conceitos organizados em sua perfeita correspondência, visto que existe a possibilidade de que diferentes doutrinas sejam levadas em considerações. Nesse sentido, as realidades sociais, em sua complexidade, deveriam ser amplamente abrangidas pelas questões abordadas. (LUPI, 2013, p. 175). Vemos com o método escolástico uma tolerância e liberdade na citação de autores pagãos, principalmente com Tomás de Aquino na defesa de Aristóteles. A Escolástica institucionalizou o debate. 


\section{AS CONTESTAÇÕES À FILOSOFIA ESCOLÁSTICA}

Embora a Escolástica tenha sua unidade em seu método de ensino, aprendido na Faculdade de Artes, ela não foi um movimento singular durante o Medievo Central. Existiram convergências e divergências em determinados objetos de estudo que versavam acerca da razão, do intelecto do homem e dos mais variados temas que pudessem garantir algum bem à sociedade.

Encontramos os primórdios do movimento escolástico com Anselmo de Bec (10331109). O monge beneditino e arcebispo de Cantuária defende que a melhor educação é aquela iniciada logo na infância, sendo o modo mais correto de moldar o indivíduo para a vida em sociedade. Bec alude à dificuldade de modelagem de um adulto ou de um recém-nascido, visto que o primeiro já está inserido na sociedade e o segundo não possui aptidões necessárias. Eram ensinados às crianças os sentidos e significados dos signos usados no discurso religioso, tais como a simbologia do Pecado Original. Quanto ao método de ensino, Anselmo compreende que se faz necessário a prática constante da cópia e da leitura, como princípios primordiais à preservação e transmissão da cultura religiosa medieval. Aos poucos vemos uma substituição da oralidade pela escrita (OLIVEIRA, 2011, p. 4-5).

Anselmo foi o primeiro escolástico, e seus escritos ganharam destaque no momento em que o poder da Igreja estava sendo contestado. O Bispo de Cantuária reconhece que a divisão entre dois dos mundos opostos, sagrado e profano, proposta pela Instituição religiosa, já não atende mais aos anseios do novo contexto (sécs. XI-XIII). Fazia-se necessária uma explicação, por parte dos homens da Igreja, das ordens sociais de uma outra maneira, não mais pautada somente entre os que oram e os homens do povo. Seus escritos têm a função de defender esse poder religioso, mas se fosse usado em paralelo às novas relações que estavam surgindo. Era preciso englobar os senhores feudais nessa nova explicação de mundo. Nesse novo modo de explicação das coisas, Anselmo, ainda no século XI, reafirma o seu posicionamento de que nem tudo está anteriormente determinado por Deus, sendo necessária a aplicação da lógica sobre os atributos divinos. Nesse sentido, para o Bispo, os homens podem alterar o destino dos eventos pois estão dotados do livre-arbítrio.

Uma outra forma de contestação ao método escolástico está presente nos escritos de Pedro Abelardo (1079-1142). O filósofo condena a falta de coesão presente nas catenas. Para o filósofo essa cadeia de citações de autoridades estava isentada da prática do diálogo, por isso defendeu uma revisão de toda metodologia em questão. 
Os embates mais acirrados foram propiciados pelas discordâncias entre os representantes da Ordem dos Franciscano e da Ordem dos Dominicanos. Na filosofia da Escolástica os Franciscanos veem os seus princípios mais admoestados e advertidos do que reafirmados (ALESSIO, 2006, p. 375). Boaventura, ministro-geral dos Frades Menores, alega que os escritos de Aristóteles são tenebrosos e perigosos à doutrina cristã. $\mathrm{O}$ frade refuta os ensinamentos neoaristotélicos, pois esses escritos não possuem a revelação cristã, em que defende unicamente a fé como método explicativo para as coisas do mundo. Os Franciscanos afirmam que o saber é um luxo supérfluo, enquanto os Dominicanos defendem que somente pelo estudo os alunos poderão pregar a ortodoxia em regiões heréticas. O modelo defendido pela Ordem dos Dominicanos promove a união da teologia natural com a teologia revelada, pois esta é superior no entendimento dos assuntos divinos.

Esses embates geraram uma crise na filosofia da Escolástica, visto que quarenta anos depois da aceitação das obras de Aristóteles, em 1277, houve retumbantes condenações aos seus escritos por Estevão Tempier, Bispo de Paris. Negaram-se 219 proposições aristotélicas, como ameaças diretas aos costumes, a fé, a Igreja e a tradição, entre elas afirmações como "Não há nada melhor do que viver como filósofo". "Os únicos sábios do mundo são os filósofos [e não os santos]". "Deus é a causa muito distante de todas as coisas". "O destino é senhor do mundo" (ALESSIO, 2006, p. 376). Ao mesmo tempo em que esses embates fomentaram uma mudança na filosofia da Escolástica, também promoveram o seu declínio.

$\mathrm{Na}$ trajetória da filosofia da Escolástica podemos perceber a impossibilidade de um método uno e monótono, na contramão a uma diversidade de vias. Pós-condenações, o método escolástico se modificou, e por isso não podemos tratá-lo como um bloco unitário, visto que já havia discussões de paradigmas entre os Franciscanos e Dominicanos. Foi uma filosofia que se modificou no tempo e no espaço e que adquiriu maior proporção, no que concerne às críticas, com as ideias de Guilherme de Ockham (1284-1347), na defesa de uma Igreja que retornasse às origens, contra a Instituição religiosa de Avignon. Ockham compreende que o papa deveria guiar e cuidar das ovelhas, e usando esse poder para dominar os homens ele se tornaria um tirano. Ademais, o guia do rebanho deveria ter cuidado para não se tornar um regente autoritário, dominador e que tenta a todo instante sobrepor o seu poder sobre os demais, como foi o caso de Gregório VII.

O século XIV foi o começo do fim da Escolástica. Com as proposições de Anselmo de Bec, Boaventura, Tomás de Aquino e Guilherme de Ockham a filosofia da Escolástica não se manteve a mesma durante o Medievo Central. Foi uma expressão, um movimento e uma 
filosofia própria do período em questão, que acompanhou e construiu o mundo medieval. Nesse sentido, assim como regente a filosofia da Escolástica também é a responsável por seu processo de destruição. Os pensadores do século XVII relegaram o Medievo ${ }^{4}$ ao obscurantismo, justificando a ampla abrangência que tivera a Teologia. Do mesmo modo, foi o século em que se negou a Escolástica como filosofia plena.

\section{CONSIDERAÇÕES FINAIS}

O método escolástico foi um guia material pois as ações dos homens estavam orientadas por suas crenças. Do mesmo modo, se consolidou como um guia mental com o surgimento das Universidades, a base da mentalidade do homem do Medievo Central. O alcance escolástico fora enorme, visto que os mais humildes eram orientados por meio da religiosidade, em que se era ensinada a sabedoria contida nas Sagradas Escrituras, resultando na propagação dos modos de agir e do pensamento cristão. Ademais, esse método sistematizou o conteúdo a ser ensinado na não separação da teoria e da prática. Somente aprendendo a doutrina, em sua totalidade, é que o aprendiz saberá fazer um bom uso do conteúdo aprendido. Nesse sentido, o ensino, a teoria e a prática foram agrupados em um só método, em questões sociais do medievo foram pautados em autoridades antigas e nas Sagradas Escrituras. Esse método recebeu o nome de Escolástica.

A Escolástica mudou e foi mudada pelas relações sociais, econômicas e políticas, sendo entendida como um pensamento expressivo dessas conjunturas. Foi uma resposta às exigências colocadas pela sociedade do período, que procurou atender a todos os segmentos da sociedade. Antes de ser uma filosofia "ela surge como resposta às novas formas de pensar e agir dos homens medievais" (CYRILO, 2016, p. 2). Funcionou como expressão de vida desses homens, organizando a vida deles. Enquanto resposta às questões colocadas pelo novo contexto, foi a filosofia que realçou um ethos religioso e social próprio do Medievo Central, em suas conexões dialéticas fundadas pelos princípios da fé e da razão. Esse aspecto vital dado à Escolástica como filosofia cristã remete-se ao conhecimento que o mestre dispunha das duas naturezas distintas de entendimento do mundo, a religiosidade cristã e a filosofia grega e romana, sob um único eixo teológico-filosófico.

\footnotetext{
${ }^{4} \mathrm{O}$ conceito carrega em si um teor preconceituoso e de desprezo, fora criado no século XVI, como negação ao período e reforçado no século XVII pelo francês Charles Fresne Du Cange e pelo alemão Christoph Keller.
} 


\section{REFERÊNCIAS}

ALESSIO, Franco. Escolástica. In: LE GOFF, Jacques; SCHMITT, Jean-Claude. Dicionário temático do Ocidente medieval. Bauru: Edusc, 2006.

CYRILO, Silvana. A escolástica como método de ensino e produção do conhecimento na universidade medieval: uma reflexão sobre a questão do respeito em Tomás de Aquino. In: CAMPOS, Marília Andrade Torales; SILVA, Monica Ribeiro da: XI Reunião Científica Regional da Associação Nacional de Pesquisa e Pós-Graduação em Educação - ANPED Sul. Paraná: Curitiba, 2016, p. 1-3.

GEERTZ, Clifford. The interpretation of culture. New York: Basic Books, 1973. (Tradução para o português: A interpretação das culturas. Rio de Janeiro: LTC, 2008).

LUPI, João Eduardo Pinto Basto. O método de argumentação na Filosofia Escolástica. Mirabilia, n. 16, p. 170-171, 2013/1.

NUNES, R. A Escolástica. In: LIBERA, A; NUNES, R. A. C. História da educação na Idade Média. São Paulo: EDUSP, 1979.

OLIVEIRA, Terezinha. Apogeu e crise de uma época: as universidades medievais. Educere et Educere, v. 1, n. 1, p. 25-26, jun./jan. 2006.

OLIVEIRA, Terezinha. Poder e escolástica no Ocidente Medieval. Dimensões, v. 25, p. 266$285,2010$.

OLIVEIRA, Terezinha. Reflexões sobre religiosidade e educação no século XIII: Boaventura de Bagnoregio, um exemplo. Maringá: Revista Brasileira de História das Religiões, v. 3, n. 9, p. 02-14, jan./jun., 2011.

OLIVEIRA, Terezinha. A formação do mestre no século XIII: um estudo sobre a sindérese e a consciência no de veritate de Tomás de Aquino. Santa Maria: Educação, vol. 44 , p. 1-21, 2019.

PADOVESE, Luigi. Introdução à teologia patrística. São Paulo: Edições Loyola, 1999.

PASTOUREAU, Michel. Une histoire Symbolique du Moyen Âge Occidental. Paris: Éditions du Seuil, 2004.

SANTIN, Rafael Henrique; OLIVEIRA, Terezinha. O método escolástico em Tomás de Aquino: um estudo no campo da História da Educação. In: OLIVEIRA, Terezinha; VISALI, Angelita: VII Jornada de Estudos Antigos e Medievais. Paraná: Maringá, 2009. p. 1-8. 